\title{
Effect of Growth Media, pH and Temperature on Yeast to Hyphal Transition in Candida albicans
}

\author{
Sayyada Ghufrana Nadeem ${ }^{1}$, Amna Shafiq ${ }^{1}$, Shazia T. Hakim ${ }^{1}$, Yasmeen Anjum², \\ Shahana U. Kazm ${ }^{3}$ \\ ${ }^{1}$ Mycology Research and Reference Institute, Department of Microbiology, Jinnah University for \\ Women, Karachi, Pakistan \\ ${ }^{2}$ Department of Botany, Jinnah University for Women, Karachi, Pakistan \\ ${ }^{3}$ IIDRL, Department of Microbiology, University of Karachi, Karachi, Pakistan \\ Email: huma_45@hotmail.com
}

Received June 19, 2013; revised July 19, 2013; accepted July 27, 2013

Copyright (c) 2013 Sayyada Ghufrana Nadeem et al. This is an open access article distributed under the Creative Commons Attribution License, which permits unrestricted use, distribution, and reproduction in any medium, provided the original work is properly cited.

\begin{abstract}
The transition of C. albicans from unicellular yeast form to filamentous form i.e., pseudohyphae and hyphae is referred to as morphogenesis. C. albicans has the ability to respond to environmental conditions and accordingly changing its cell morphology. Three main morphological forms of $C$. albicans are unicellular yeast, pseudohyphae and hyphae. The effect of different growth media (Horse serum medium, RPMI-1640, MSGB), incubation temperatures $\left(34^{\circ} \mathrm{C}, 37^{\circ} \mathrm{C}\right.$, $\left.40^{\circ} \mathrm{C}\right)$ and $\mathrm{pH}$ values $(5.4,6.4,7.4)$ on germ tube production by C. albicans was evaluated. Horse serum medium noticeably promotes filamentation while RPMI-1640 medium shows moderate filamentation and MSGB media shows moderately low filamentation. The germ tube of C. albicans developed early in $1.5 \mathrm{hr}$ at high temperature i.e., $40^{\circ} \mathrm{C}$. Incubation temperature of $37^{\circ} \mathrm{C}$ was associated with highest germ tube formation while $34^{\circ} \mathrm{C}$ shows low filamentation. $\mathrm{A} \mathrm{pH}$ of 5.4 also induces low filamentation, $\mathrm{pH} 6.4$ gives moderately lower than $\mathrm{pH}$ 7.4. A pH of 7.4 was best suited for germ tube induction. The peak of mycelium production appears between 1.5 and $6 \mathrm{hr}$ after inoculation of $C$. albicans culture. These results suggested that environmental factors are important in selectively favoring yeast or hyphal form, most important being the growth medium, incubation temperature and external $\mathrm{pH}$ value.
\end{abstract}

Keywords: Candida albicans; Filamentation; Germ Tube; Morphogenesis; Pathogenesis

\section{Introduction}

Candida albicans is the opportunistic fungal pathogen that lives as commensal on different locations of human body such as in gastrointestinal and genitourinary tracts in about $70 \%$ of humans. However, it can convert from harmless commensal into disease causing pathogen in response to change in host environment. C. albicans is the most common fungus associated with human infections, especially in immune compromised patients [1]. Broadly, the infections caused by C. albicans can be divided into two categories: mucosal and systemic. Mucosal infections affect various mucous membranes of the body surfaces such as oropharyngeal mucosa and vaginal mucosa. Vaginal candidiasis is quite common in women and approximately $75 \%$ of all women suffer from vaginal candidiasis once in their lifetime. Systemic infection involves the spread of $C$. albicans to the blood stream and to the major organs. Mucosal infections of C. albicans are often benign but systemic infections are usually fatal [2-6].

Morphogenesis is an essential trait in the pathogenic fungus $C$. albicans and it is clearly required for virulence [7-11]. Morphogenesis in C. albicans is defined as transition from unicellular yeast form to filamentous form (pseudohyphae or hyphae) [12]. It can grow in a variety of morphological forms such as yeast, pseudohyphae and hyphae [13,14]. C. albicans also can form chlamydospores that is to say; thick walled spherical cells or asexual spores which develop over pseudohyphal support cells and appear under unfavourable environmental conditions $[13,15]$. In pseudohyphae daughter bud elongates and, after septum formation, the daughter cell remains attached to the mother cell. The elongation of buds in pseudohyphae can be so extreme that these filaments can superficially resemble hyphae. Because of this, it is often 
useful to be able to refer to pseudohyphae and hyphae collectively and we will use the term 'filamentous' for this purpose [13]. However, hyphae are narrower than pseudohyphal cells $(2 \mathrm{~mm})$ and have parallel walls with no obvious constriction at the site of septation [13]. Germ tubes are the initial projections observed when $C$. albicans switches from yeast form to hyphal growth [16]. Growth is polarized in C. albicans hypha, with continuous apical growth throughout the cell cycle and parallel cell walls at the septal junctions. In contrast, the growth of pseudohypha and blastophores is only limited to the apical tip during the initial part of the cell cycle [17]. Pseudohypha can also be distinguished from true hypha on the basis of their morphological index which quantifies the dimensions of cell compartments. Alternatively they can be distinguished on the basis of the positions of their septal junctions. These lie at the bud neck for pseudohypha, and within the germ tube for emerging hypha [13]. Hyphae, pseudohyphae and yeast differ from each other in the rate and order of cell cycle events [18].

Morphogenesis is interrelated to the pathogenesis of $C$. albicans. Adherence has been shown to play critical role in the pathogenesis of infections. Germ tubes, that are short hyphal elements, are important in the adherence of organism to the host epithelium [19-21]. Hypha of $C$. albicans are also important for tissue destruction and host invasion [22]. The yeast form of C. albicans also have virulence attribute and is thought to promote dissemination within the blood stream and establishment of infection at distant sites $[8,13,23,24]$. Several researchers have investigated that hyphal form is more virulent than yeast form [25-27]. The principal determinant in the development of disease is the ability of $C$. albicans to switch between yeast and hyphal forms rather than the individual morphologies [28].

There are various host defense mechanisms against $C$. albicans infections which mainly include phagocytosis of fungal cells by the cells of innate immune system (macrophages and neutrophils). Phagocytic clearance of fungal pathogens may be considered to consist of four distinct stages; 1) accumulation of phagocytes at the site where fungal cells are located; 2) recognition of fungal pathogen by specific receptors [29]; 3) engulfment of fungal cells bound to the phagocyte cell membrane, and 4) processing of engulfed cells within phagocytes by fusion with lysosomal vesicles to form the phagolysosome [30]. Yeast forms of C. albicans cells are more effectively engulfed by macrophages as compared to hyphal forms. Hyphal cells are engulfed at a slower rate than yeast cells. The delayed engulfment may result in the detachment of fungal cell [31]. Furthermore, the yeast-form of $C$. albicans cells that are phagocytosed by macrophages switches to the hyphal form and escape the macrophages. This switching is particularly important in escaping the defense mechanism of the host [7].
Morphological changes between the yeast and the various filamentous forms occur in response to alterations in the growth conditions. Parameters that promote hyphal development in vitro include a growth temperature above $35^{\circ} \mathrm{C}$, a $\mathrm{pH}$ greater than 6.5 , nitrogen and/or carbon starvation, nonfermentable carbon sources, low oxygen concentrations, and a wide range of chemicals including $\mathrm{N}$-acetylglucosamine, proline (and other amino acids) and alcohols. Serum is one of the most potent inducers of hyphal development [32-34]. The effect of serum is complex but it is proposed to act, in part, by conferring amino acid starvation [35]. Two known inducers of hyphal formation, $\mathrm{N}$-acetylglucosamine (GlcNAc) and proline, may contribute to the serum effect since they are generated by degradation of serum (glyco-) proteins [36]. It is well established that a $\mathrm{pH}$ around neutrality favours hyphal development of $C$. albicans in vitro, while a low $\mathrm{pH}(\mathrm{pH}<6.5)$ blocks hyphal formation and stimulates growth of the yeast form [37]. Growth of cells in the yeast form is promoted by the inoculums above $10^{6}$ cells $/ \mathrm{ml}$, a growth temperature below $35^{\circ} \mathrm{C}$, a pH of less than 6.5, glucose and ammonium salts [2].

Compared to liquid medium, induction on solid media appears to represent a weaker hypha-inducing condition, because minor defects in filamentation show a defective phenotype on solid but not in liquid media [36]. So the mycelial tendency is stronger in liquid than on solid media [38] and stationary phase cells are most responsive to hyphal and pseudohyphal induction signals [18].

The present work is done to study yeast to hyphal transition as influenced by growth media, temperature and external $\mathrm{pH}$ value. Different growth media are used to study the nutritional effect on C. albicans with respect to temperature and $\mathrm{pH}$. Also effect of temperature and $\mathrm{pH}$ is observed individually.

\section{Materials \& Methods}

\subsection{Target Culture}

C. albicans.

\subsection{Inoculum Preparation}

The culture of C. albican was kept on SDA at $4^{\circ} \mathrm{C}$. Culture from plate was inoculated in YEPD broth and incubated at $37^{\circ} \mathrm{C}$ for $24 \mathrm{hrs}$. Yeast cells were washed twice by centrifugation with sterile water and resuspended in water. The turbidity of suspension was adjusted to 0.5 Mc Farland solutions $\left(1 \times 10^{6}\right.$ to $\left.5 \times 10^{6} \mathrm{CFU} / \mathrm{ml}\right)$.

\subsection{Effect of Growth Media}

Three growth media were used to study their effect on morphogenesis. These were Horse Serum media, RPMI1640 and Modified Sabourauds Glucose broth (MSGB). 
The Horse Serum media contain the following: $900 \mathrm{ml}$ of Yeast Extract Peptone Dextrose broth (YEPD) and 900 $\mathrm{ml}$ of serum. YEPD is first autoclave, cool and then serum was added to it. The final $\mathrm{pH}$ of the media was 6.8. RPMI-1640 media contain the following (per $1000 \mathrm{ml}$ of distill water: Inorganic Salts $\left(100 \mathrm{mg}\right.$ of $\mathrm{Ca}\left(\mathrm{NO}_{3}\right)_{2} \cdot 4 \mathrm{H}_{2} \mathrm{O}$, $400 \mathrm{mg}$ of $\mathrm{KCl}, 48.80 \mathrm{mg}$ of $\mathrm{MgSO}_{4}, 6000 \mathrm{mg}$ of $\mathrm{NaCl}$, $800 \mathrm{mg}$ of $\mathrm{Na}_{2} \mathrm{HPO}_{4}$ and $2000 \mathrm{mg}$ of $\mathrm{NaHCO}_{3}$ ), Amino acids (200 $\mathrm{mg}$ of L-arginine, $56.82 \mathrm{mg}$ of L-asparagine. $\mathrm{H}_{2} \mathrm{O}, 20 \mathrm{mg}$ of L-aspartic acid, $65.20 \mathrm{mg}$ of L-cystine. $2 \mathrm{HCl}, 20 \mathrm{mg}$ of L-glutamic acid, $300 \mathrm{mg}$ of L-glutamine, $10 \mathrm{mg}$ of glycine, $15 \mathrm{mg}$ of L-histidine, $20 \mathrm{mg}$ of hydroxy-L-proline, $50 \mathrm{mg}$ of L-isoleucine, $50 \mathrm{mg}$ of Lleucine, $40 \mathrm{mg}$ of L-lysine. $\mathrm{HCl}, 15 \mathrm{mg}$ of L-methionine, $15 \mathrm{mg}$ of L-phenylalanine, $20 \mathrm{mg}$ of L-proline, $30 \mathrm{mg}$ of L-serine, $20 \mathrm{mg}$ of L-threonine, $5 \mathrm{mg}$ of L-tryptophan, $28.83 \mathrm{mg}$ of L-tyrosine. $2 \mathrm{Na} \cdot 2 \mathrm{H}_{2} \mathrm{O}$ and $20 \mathrm{mg}$ of $\mathrm{L}-$ valine), Vitamins ( $0.20 \mathrm{mg}$ of biotin, $0.25 \mathrm{mg}$ of D-calcium pantothenate, $3 \mathrm{mg}$ of choline chloride, $1 \mathrm{mg}$ of folic acid, $35 \mathrm{mg}$ of i-Inositol, $1 \mathrm{mg}$ of nicotinamide, 1 $\mathrm{mg}$ of $\mathrm{p}$-aminobenzoic acid, $1 \mathrm{mg}$ of pyridoxine. $\mathrm{HCl}$, $0.20 \mathrm{mg}$ of riboflavin, $1 \mathrm{mg}$ of thiamine. $\mathrm{HCl}$ and 0.05 $\mathrm{mg}$ of vitamin B12) and others (2000 mg of D-glucose, 1 $\mathrm{mg}$ of glutathione and $5 \mathrm{mg}$ of phenol red). The final $\mathrm{pH}$ of the media was 7.4. MSGB media contain the following (per $1000 \mathrm{ml}$ of distill water): (10 g of peptone and 2 $\mathrm{g}$ of D-glucose). The final $\mathrm{pH}$ of the media was 7.4. Media were warmed to their incubation temperature before inoculation [39]. Inoculate $1 \mathrm{ml}$ culture in $9 \mathrm{ml}$ media. After inoculation of culture, the tubes were kept in water bath shaker at $37^{\circ} \mathrm{C}$ for 12 hrs.

\subsection{Effect of Temperature}

C. albicans was inoculated in MSGB media under $\mathrm{pH} 7.4$ and incubated at different temperatures of $34^{\circ} \mathrm{C}, 37^{\circ} \mathrm{C}$ and $40^{\circ} \mathrm{C}$ for 12 hrs.

\subsection{Effect of $\mathrm{pH}$}

The influence of $\mathrm{pH}$ was observed by inoculating culture in MSGB media under different $\mathrm{pH}$ values of 5.4, 6.4 and 7.4 providing incubation of $37^{\circ} \mathrm{C}$ for $12 \mathrm{hrs}$.

\subsection{Growth and Mycelium Formation}

At intervals (1.5 hr) during growth, the cell concentration was determined using hemocytometer. Yeast cell buds emerging from mother cells are counted as a separate cell if the bud is at least one-half the size of the mother cell [40]. Count the cells forming germ tube and express this as a percentage [39].

\section{Results \& Discussions}

C. albicans is the most frequent opportunistic fungal pathogen of humans. One of the major virulence factors is its ability to switch between yeast and filamentous form. C. albicans morphogenetic conversions are important for multiple aspects of $C$. albicans biology and pathogenicity. Environmental factors are vital for control of the morphology of C. albicans and a wide variety of environmental factors is responsible for this morphological transition. Most important factors are the growth temperature of $37^{\circ} \mathrm{C}$, neutral $\mathrm{pH}$, growth medium, carbon starvation, low oxygen concentration and a wide range of chemicals including $\mathrm{N}$-acetylglucosamine, proline (and other amino acids) and alcohols [32]. These individual or combinations of factors are responsible for the transition of C. albicans from yeast to filamentous form. The combined effect of temperature $37^{\circ} \mathrm{C}$ and a neutral $\mathrm{pH}$ have been observed in a number of past studies [41-43]. In the present work effect of growth medium, $\mathrm{pH}$ and temperature is observed. The effect of $\mathrm{pH}$ was observed while keeping the temperature constant at $37^{\circ} \mathrm{C}$. Similarly, the effect of temperature was observed while keeping the $\mathrm{pH}$ constant at 7.

The three growth media used for inducing filamentation in C. albicans were Horse serum media, RPMI-1640 and Modified Sabouraud's Glucose Broth (MSGB). These growth medium were tested for observing the effect of nutrients on morphogenesis in C. albicans. The importance of nutrient factors that induce germ tube formation in C. albicans has been reported in previous papers [44-47].

Horse serum, that is natural ingredients of hemin, hormones and other blood serum constituents, appeared to be necessary for germ tube formation and hence increased pathogenicity for most C. albicans strains [23, $45,48]$. We observed noticeably increased filamentation in horse serum (Figure 1) about 52\% after 4.5 hrs and this percentage of germ tube forming cells gradually decreases from 7.5 to 10.5 hr (Table 1). RPMI-1640 medium containing high level of glucose $(0.45 \%)$, high phosphate $(6 \mathrm{~g} / \mathrm{L})$, amino acids and biotin reduces the ability of $C$. albicans that was isolated from oral cavity to form germ tube [39]. As C. albicans activate hyphal development in response to glucose, phosphate, amino acids and biotin starvation $[44,49,50]$. On the other hand, results suggested moderate filamentation about $44 \%$ in RPMI-1640 medium after 4.5 hr of inoculation of culture. However, influence of amino acids and vitamins for initiation of germ tube formation has been also reported in previous papers [45,49,51]. In another paper [39] it was also reported that $C$. albicans isolated from genitourinary tract show detectable filamentation in RPMI-1640 medium. Modified Sabouraud's Glucose Broth (MSGB) was also used for germ tube formation in C. albicans. This media was use to observe response of $C$. albicans to glucose starvation [39]. Effect of glucose starvation on 



Figure 1. Formation of germ tube in C. albicans after $4.5 \mathrm{hr}$ at $37^{\circ} \mathrm{C}$ in (a) Horse serum, (b) RPMI-1640 and (c) MSGB magnification: $40 \times$.

Table 1. Effect of different growth media in germ tube production in Candida albicans incubated at $37^{\circ} \mathrm{C}$ for $12 \mathrm{hr}$.

\begin{tabular}{|c|c|c|c|c|c|c|c|}
\hline \multirow[b]{2}{*}{ Yeast Strain } & \multirow[b]{2}{*}{ Incubation period } & \multicolumn{2}{|c|}{ Horse Serum medium } & \multicolumn{2}{|c|}{ RPMI-1640 } & \multicolumn{2}{|c|}{ MSGB } \\
\hline & & $\begin{array}{c}\text { Yeast count } / \mathrm{ml} \\
\times 10^{6}\end{array}$ & $\begin{array}{l}\text { \% of } \\
\text { CFGT }\end{array}$ & $\begin{array}{l}\text { Yeast count } / \mathrm{ml} \\
\times 10^{6}\end{array}$ & $\%$ of CFGT & $\begin{array}{c}\text { Yeast count } / \mathrm{ml} \\
\times 10^{6}\end{array}$ & $\%$ of CFGT \\
\hline \multirow{8}{*}{$\begin{array}{l}\text { Candida } \\
\text { albicans }\end{array}$} & 1.5 & 1.0 & 24 & 1.0 & 18 & 1.0 & 10 \\
\hline & 3.0 & 1.0 & 44 & 2.5 & 32 & 2.0 & 24 \\
\hline & 4.5 & 2.0 & 52 & 3.0 & 44 & 2.0 & 40 \\
\hline & 6.0 & 2.0 & 38 & 3.5 & 36 & 4.5 & 32 \\
\hline & 7.5 & 3.0 & 24 & 4.5 & 12 & 7.0 & 22 \\
\hline & 9.0 & 4.0 & 28 & 4.5 & 16 & 8.0 & 18 \\
\hline & 10.5 & 5.5 & 30 & 8.5 & 18 & 9.5 & 10 \\
\hline & 12.0 & 6.5 & 30 & 17.0 & 20 & 11.0 & 4 \\
\hline
\end{tabular}

filamentation of $C$. albicans has also been reported in a previous paper [52]. MSGB used here shows 40\% filamentation after $4.5 \mathrm{hr}$ of inoculation of culture. It gives comparable low filamentation than RPMI-1640 media.

The effect of different temperatures i.e., $34^{\circ} \mathrm{C}, 37^{\circ} \mathrm{C} \&$ $40^{\circ} \mathrm{C}$ were used to detect germ tube formation in C. albicans keeping $\mathrm{pH} 7$ of the medium. Hyphae are readily induced from unbudded yeast cells by a growth temperature of $37^{\circ} \mathrm{C}$ [13] and according to the previous paper [39] $37^{\circ} \mathrm{C}$ was optimal for filamentation, $34^{\circ} \mathrm{C}$ was suitable while higher temperature results in gradual decrease in yeast growth. In the experiment performed no filamentation seen at $34^{\circ} \mathrm{C}$ after $1.5 \mathrm{hr}$ while $14 \%$ filamentation seen after $4.5 \mathrm{hr}$ (Figure 2(a)), at $37^{\circ} \mathrm{C} 42 \%$ germ tube formation seen after $4.5 \mathrm{hr}$ (Figure 2(b)) while at $40^{\circ} \mathrm{C}$ rapid germ tube formation (28\%) seen after $1.5 \mathrm{hr}$. (Figure 2(c)) and peak filamentation (about 36\%) seen after $4.5 \mathrm{hr}$ (Table 2). The influence of incubation temperature in dimorphism of $C$. albicans has been reported by many workers [5,36,50,53,54].

In the experiment performed, effect of different $\mathrm{pH}$ values i.e., 5.4, 6.4 and 7.4 were used to study germ tube formation in $C$. albicans keeping the temperature constant at $37^{\circ} \mathrm{C}$ (Figure 3). The peak germ tube formation was seen at pH 7.4 and about $40 \%$ cells form germ tube after 4.5 hr of culture inoculation (Table 3). It was also reported that the extracellular $\mathrm{pH}$ is one of the environmental factors that modified the physiology of the cell [55].
Moreover, the combined effect of growth temperature and $\mathrm{pH}$ in the induction of hyphae and pseudohyphae has also been observed previously [13]. The optima for filamentation in C. albicans are $\mathrm{pH} 7$ and $37^{\circ} \mathrm{C}$ temperature. However, increase in either parameters between these optima or parameter limits result in significantly low or no filamentation [37]. When cells are released into fresh media at $37^{\circ} \mathrm{C}$ but at $\mathrm{pH} 7$, the cells are synchronously evaginated to form germ tube. These cell cultures continue to grow as mycelia form as long as $\mathrm{pH}$ is 7 and temperature is $37^{\circ} \mathrm{C}$.

The peak of germ tube production by C. albicans appeared between 1.5 to $6.0 \mathrm{hr}$ observed in different growth media and at different temperature and $\mathrm{pH}$ values and it gradually decreases after $6.0 \mathrm{hr}$. However, it was also observed in most of the cases that after decrease in \% of CFGT, it starts to increase after $10.5 \mathrm{hr}$. The reason behind may be that the effect of growth medium, temperature and $\mathrm{pH}$ that should be determined at regular intervals in $12 \mathrm{hr}$ a day [39] is not done so as it is not possible, therefore, the experiment was splitted in to two days and observations were taken at regular intervals in $6 \mathrm{hr}$ a day. Therefore, fluctuations in percentage of cells forming germ tube may be seen most of the time.

We concluded that germ tube production in C. albicans is induced by providing individual or combination of environmental factors that are similar to hostile conditions in human host. Because the ability of C. albicans to switch in to different morphological forms is actually 

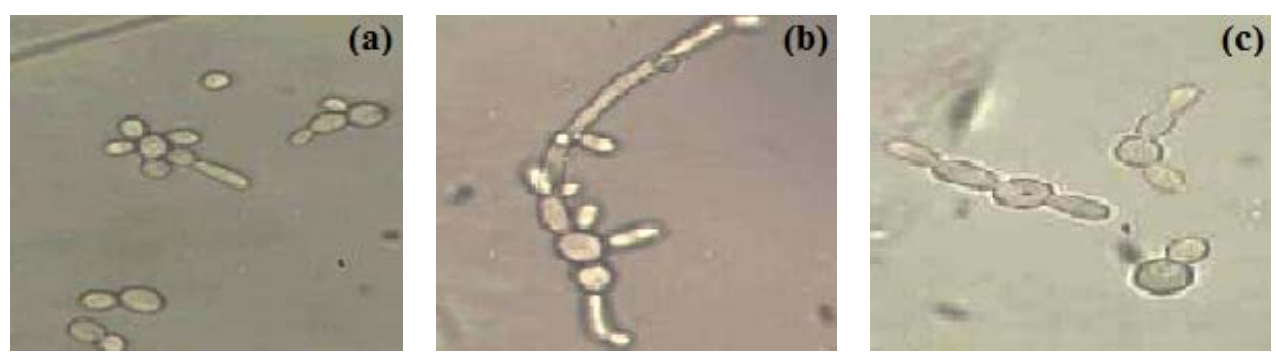

Figure 2. Short outgrowth from budding yeast is seen after $4.5 \mathrm{hr}$ in MSGB at (a) $34^{\circ} \mathrm{C}$, long filament seen at (b) $37^{\circ} \mathrm{C}$ and a germ tube after $1.5 \mathrm{hr}$ at (c) $40^{\circ} \mathrm{C}$. Magnification: $40 \times$.
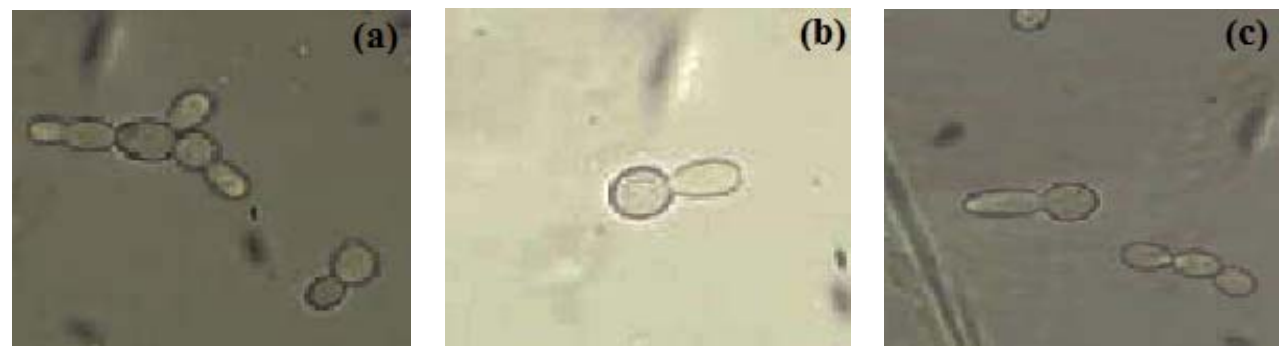

Figure 3. Budding yeast and pseudohyphal cell at $37^{\circ} \mathrm{C}$ in MSGB under (a) pH 5.4, short elongation from yeast cell under (b) pH 6.4 and a comparable long germ tube under (c) pH 7.4. Magnification: $40 \times$.

Table 2. Effect of incubation temperature in germ tube production in Candida albicans.

\begin{tabular}{|c|c|c|c|c|c|c|c|}
\hline \multirow[b]{2}{*}{ Yeast Strain } & \multirow{2}{*}{$\begin{array}{c}\text { Incubation } \\
\text { period }\end{array}$} & \multicolumn{2}{|c|}{ Temperature $=34^{\circ} \mathrm{C}$} & \multicolumn{2}{|c|}{ Temperature $=37^{\circ} \mathrm{C}$} & \multicolumn{2}{|c|}{ Temperature $=40^{\circ} \mathrm{C}$} \\
\hline & & $\begin{array}{c}\text { Yeast count } / \mathrm{ml} \\
\times 10^{6}\end{array}$ & $\%$ of CFGT & $\begin{array}{c}\text { Yeast count } / \mathrm{ml} \\
\times 10^{6}\end{array}$ & $\%$ of CFGT & $\begin{array}{c}\text { Yeast count } / \mathrm{ml} \\
\times 10^{6}\end{array}$ & $\%$ of CFGT \\
\hline \multirow{8}{*}{$\begin{array}{l}\text { Candida } \\
\text { albicans }\end{array}$} & 1.5 & 1.0 & 0 & 1.5 & 14 & 1.5 & 28 \\
\hline & 3.0 & 1.5 & 8 & 2.0 & 22 & 2.0 & 30 \\
\hline & 4.5 & 3.0 & 14 & 2.0 & 42 & 2.0 & 36 \\
\hline & 6.0 & 3.5 & 12 & 3.0 & 40 & 2.5 & 36 \\
\hline & 7.5 & 4.0 & 10 & 3.5 & 24 & 4.0 & 18 \\
\hline & 9.0 & 5.0 & 10 & 3.5 & 16 & 4.0 & 8 \\
\hline & 10.5 & 6.5 & 8 & 4.5 & 8 & 4.5 & 2 \\
\hline & 12.0 & 9.5 & 4 & 6.5 & 8 & 5.5 & 6 \\
\hline
\end{tabular}

Table 3. Effect of pH values in germ tube production in Candida albicans cultivated in MSGB at $37^{\circ} \mathrm{C}$ for $12 \mathrm{hr}$. of incubation.

\begin{tabular}{|c|c|c|c|c|c|c|c|}
\hline \multirow[b]{2}{*}{ Yeast Strain } & \multirow{2}{*}{$\begin{array}{c}\text { Incubation } \\
\text { period }\end{array}$} & \multicolumn{2}{|c|}{$\mathrm{pH}=5.4$} & \multicolumn{2}{|c|}{$\mathrm{pH}=6.4$} & \multicolumn{2}{|c|}{$\mathrm{pH}=7.4$} \\
\hline & & $\begin{array}{l}\text { Yeast count } / \mathrm{ml} \\
\times 10^{6}\end{array}$ & $\%$ of CFGT & $\begin{array}{c}\text { Yeast count } / \mathrm{ml} \\
\times 10^{6}\end{array}$ & $\%$ of CFGT & $\begin{array}{l}\text { Yeast count } / \mathrm{ml} \\
\times 10^{6}\end{array}$ & $\%$ of CFGT \\
\hline \multirow{8}{*}{$\begin{array}{l}\text { Candida } \\
\text { albicans }\end{array}$} & 1.5 & 1.5 & 0 & 1.2 & 6 & 1.3 & 16 \\
\hline & 3.0 & 3.5 & 6 & 1.7 & 10 & 2.2 & 22 \\
\hline & 4.5 & 4.5 & 10 & 2.0 & 24 & 2.5 & 40 \\
\hline & 6.0 & 5.0 & 12 & 2.8 & 24 & 4.6 & 36 \\
\hline & 7.5 & 5.4 & 8 & 3.4 & 16 & 4.8 & 24 \\
\hline & 9.0 & 9.5 & 8 & 5.4 & 10 & 7.3 & 16 \\
\hline & 10.5 & 10.5 & 10 & 8.0 & 12 & 10.0 & 10 \\
\hline & 12.0 & 15.1 & 12 & 12.0 & 10 & 14.0 & 14 \\
\hline
\end{tabular}


means of surviving under unfavorable conditions. Therefore, morphogenesis in C. albicans is considered important in its pathogenesis.

Several experimental approaches have been applied to the investigation of morphogenesis in C. albicans. The principal objective of research on morphogenesis in $C$. albicans is to define and analyze the expression of molecules that determine cell shape [14].

\section{REFERENCES}

[1] J. Schulze and U. Sonnenborn, "Yeast in the Gut: From Commensals to Infectious Agents,” Deutsches Arzteblatt, Vol. 106, No. 51-52, 2009, pp. 837-842.

[2] F. C. Odds, "Candida and Candidosis," 5th Edition, Baillière Tindall, London, 1988.

[3] D. R. Soll, M. Staebell, C. Langtimm, M. Pfaller, J. Hicks and T. V. G Rao, "Multiple Candida Strains in the Course of a Single Systemic Infection," Journal of Clinical Microbiology, Vol. 26, No. 8, 1988, pp. 1448-1459.

[4] J. D. Sobel, "Vaginitis," New England Journal of Medicine, Vol. 337, No. 26, 1997, pp. 1896-1903. doi:10.1056/NEJM199712253372607

[5] R. A. Calderone, "Candida and Candidiasis," ASM Press, Washington DC, 2002.

[6] J. A. Sexton, V. Brown, and M. Johnston, "Regulation of Sugar Transport Andmetabolism by the Candida albicans Rgt1 Transcriptional Repressor,” Yeast, Vol. 24, No. 10, 2007, pp. 847-860. doi:10.1002/yea.1514

[7] H. J. Lo, J. R. Kohler, B. Di Domenico, D. Loebenberg, A. Cacciapuoti and G. R. Fink, "Nonfilamentous C. albicans Mutants Are a Virulent,” Cell, Vol. 90, No. 5, 1997, pp. 939-949. doi:10.1016/S0092-8674(00)80358-X

[8] B. R. Braun, W. S. Head, M. X. Wang and A. D. Johnson, "Identification and Characterization of TUP1-Regulated Genes in C. albicans,” Genetics, Vol. 156, No. 1, 2000, pp. 31-44.

[9] B. R. Braun, D. Kadosh and A. D. Johnson, "NRG1, a Repressor of Filamentous Growth in C. albicans, Is DownRegulated during Filament Induction,” EMBO Journal, Vol. 20, No. 17, 2001, pp. 4753-4761. doi:10.1093/emboj/20.17.4753

[10] A. M. Murad, P. Leng, M. Straffon, J. Wishart, S. Macaskill, D. MacCallum, et al., "NRG1 Represses YeastHypha Morphogenesis and Hypha-Specific Gene Expression in C. albicans," EMBO Journal, Vol. 20, No. 17, 2001, pp. 4742-4752. doi:10.1093/emboj/20.17.4742

[11] S. P. Saville, A. L. Lazzell, C. Monteagudo and J. L. Lopez-Ribot, "Engineered Control of Cell Morphology in Vivo Reveals Distinct Roles for Yeast and Filamentous Forms of C. albicans during Infection," Eukaryotic Cell, Vol. 2, No. 5, 2003, pp. 1053-1060. doi:10.1128/EC.2.5.1053-1060.2003

[12] M. S. A Khan, I. Ahmad, F. Aqil, M. Owais, M. Shahid and J. Musarrat, "Virulence and Pathogenicity of Fungal Pathogens with Special Reference to C. albicans," In: I. Ahmad, M. Owais, M. Shahid and F. Aqil, Eds., Combating Fungal Infections: Problems and Remedy, Springer-
Verlag, Berlin, 2010, pp. 21-45. doi:10.1007/978-3-642-12173-9 2

[13] P. Sudbery, N. Gow and J. Berman, "The Distinct Morphogenic States of Candida albicans," Trends in Microbiology, Vol. 12, No. 7, 2004, pp. 317-324. doi:10.1016/j.tim.2004.05.008

[14] L. A. Merson-Davies and F. C. Odds, "A Morphology Index for Characterization of Cell Shape in C. albicans," Journal of General Microbiology, Vol. 135, No. 11, 1989, pp. 3143-3152.

[15] M. Montazeri and H. G. Hedrick, "Factors Affecting Spore Formation in a Candida albicans Strain,” Applied and Environmental Microbiology, Vol. 47, No. 6, 1984, pp. 1341-1342.

[16] Y. L. Yang, "Virulence Factors of Candida Species," Journal of Microbiology Immunology and Infection, Vol. 36, No. 4, 2003, pp. 223-228.

[17] H. Court and P. Sudbery, "Regulation of Cdc42 GTPase Activity in the Formation of Hyphae in C. albicans," Molecular Biology of the Cell, Vol. 18, No. 1, 2007, pp. 265281. doi:10.1091/mbc.E06-05-0411

[18] J. Berman, "Morphogenesis and Cell Cycle Progression in C. albicans," Current Opinion in Microbiology, Vol. 9, No. 6, 2006, pp. 595-601.

[19] L. H. Kimura and N. N. Pearsall, "Adherence of C. albicans to Human Vaginal and Buccal Epithelial Cells," Journal of Infectious Diseases, Vol. 21, No. 1, 1978, pp. 64-68. doi:10.1016/j.mib.2006.10.007

[20] J. C. Lee and R. D. King, "Characterization of C. albicans Adherence to Human Vaginal Epithelial Cells in Vitro," Infection and Immunology, Vol. 41, No. 3, 1983, pp. 1024-1030.

[21] J. D. Sobel, G. Muller and H. R. Buckley, "Critical Role of Germ Tube Formation in the Pathogenesis of Candidal Vaginitis," Infection and Immunology, Vol. 44, No. 3, 1984, pp. 576-580.

[22] J. Berman and P. E. Sudbery, "C. albicans: A Molecular Revolution Built on Lessons from Budding Yeast,” Nature Reviews Genetics, Vol. 3, No. 12, 2002, pp. 918-930. doi:10.1038/nrg948

[23] N. A. R. Gow, "Cell Biology and Cell Cycle of Candida albicans,” In: R. A. Calderone, Ed., Candida and Candidiasis, American Society for Microbiology, Washington, DC, 2002, pp. 145-158.

[24] P. Sundstrom, "Candida albicans Hypha Formation and Virulence,” In: J. Heitman, Ed., Molecular Principles of Fungal Pathogenesis, American Society for Microbiology, Washington DC, 2006, pp. 45-47.

[25] D. W. Hill and L. P. Gerbhardt, "Morphological Transformation of Candida albicans in Tissues of Mice," Proceedings of the Society for Experimental Biology and Medicine, Vol. 92, No. 2, 1988, pp. 640-644.

[26] P. J. Kozinn, C. L. Taschdjian and J. J. Burchall., "Transmission of P-32 Labeled Candida albicans to Newborn Mice at Birth,” American Journal of Diseases of Children, Vol. 99, No. 1, 1960, pp. 31-34.

[27] G. Young, "The Process of Invasion and the Persistence of Candida albicans Injected Intraperitoneally into Mice,” 
Journal of Infectious Diseases, Vol. 102, No. 2, 1964, pp. 114-120. doi:10.1093/infdis/102.2.114

[28] N. A. Gow, A. J. Brown and F. C. Odds, "Fungal Morphogenesis and Host Invasion," Current Opinion in Microbiology, Vol. 5, No. 4, 2002, pp. 366-371.

[29] G. D. Brown, "Innate Antifungal Immunity: The Key Role of Phagocytes,” Annual Review of Immunology, Vol. 29, No. 1, 2001, pp. 1-21. doi:10.1146/annurev-immunol-030409-101229

[30] R. Kaposzta, L. Marodi, M. Hollinshead, S. Gordon and R. P. da Silva, "Rapid Recruitment of Late Endosomes and Lysosomes in Mouse Macrophages Ingesting Candida albicans,” Journal of Cell Science, Vol. 112, No. 19, 1999, pp. 3237-3248.

[31] L. E. Lewis, J. M. Bain, C. Lowes, C. Gillespie, F. M. Rudkin, et al., "Stage Specific Assessment of Candida albicans Phagocytosis by Macrophages Identifies Cell Wall Composition and Morphogenesis as Key Determinants,” PLOS Pathogens, Vol. 8, No. 3, 2012, Article ID: e1002578.

[32] A. J. P. Brown, "Expression of Growth Form-Specific Factors during Morphogenesis in C. albicans," In: R. Calderone, Ed., Candida and Candidiasis, ASM Press, Washington DC, 2002, pp. 87-93.

[33] A. R. Holmes and M. G. Shepherd, "Proline Induced Germ-Tube Formation in C. albicans: Role of Proline Uptake and Nitrogen Metabolism," Journal of General Microbiology, Vol. 133, No. 11, 1987, pp. 3219-3228.

[34] E. G. Mattia, G. Corruba, L. Angiolella and A. Casone, "Induction of Germ Tube Formation by N-acetyl-D Glucosamine in Candida albicans: Uptake of Inducer and Germinative Response,” Journal of Bacteriology, Vol. 152, No. 2, 1982, pp. 555-562.

[35] G. Tripathi, C. Wiltshire, S. Macaskill, H. Tournu, S. Budge and A. J. Brown, "Gcn4 Coordinates Morphogenetic and Metabolic Responses to Amino Acid Starvation in Candida albicans,” EMBO Journal, Vol. 21, No. 20, 2002, pp. 5448-5456. doi:10.1093/emboj/cdf507

[36] J. F. Ernst, "Transcription Factors in Candida albicans-Environmental Control of Morphogenesis," Microbiology, Vol. 146, No. 8, 2000, pp. 1763-1774.

[37] J. Buffo, M. A. Herman and D. R. Soll, "A Characterization of pH-Regulated Dimorphism in Candida albicans," Mycopathologia, Vol. 85, No. 1-2, 1984, pp. 21-30. doi:10.1007/BF00436698

[38] D. O. McClary, "Factors Affecting the Morphology of Candida albicans," Annals of the Missouri Botanical Gardens, Vol. 39, No. 2, 1952, pp. 137-164. doi: $10.2307 / 2394509$

[39] S. Kabli, "Morphogenesis of Two Candida albicans Strains as Influenced by Growth Media, pH Value and Incubation Temperature," American-Eurasian Journal of Agriculture and Environmental Science, Vol. 1, No. 2, 2006, pp. 127-132.

[40] White Labs, “Cell Counting/Viability Testing,” 2013. http://www.whitelabs.com/content/cell-countingviabilitytesting-0

[41] E. G. Evans, F. C. Odds and K. T. Holland, "Optimum Conditions for Initiation of Filamentation in Candida al- bicans," Canadian Journal of Microbiology, Vol. 21, No. 3, 1975, pp. 338-342. doi:10.1139/m75-048

[42] K. L. Lee, H. R. Buckley and H. R. Campbell, “An Amino Acid Liquid Synthetic Medium for Development of Mycellal and Yeast Forms of Candida albicans," Medical Mycology, Vol. 13, No. 2, 1975, pp. 148-153. doi:10.1080/00362177585190271

[43] P. Auger and J. Joly, "Factors Influencing Germ Tube Production in Candida albicans," Mycopathologia, Vol. 61, No. 3, 1977, pp. 183-186. doi:10.1007/BF00468014

[44] V. Paranjape and A. Datta, "Role of Nutritional Status \& the Cell in $\mathrm{pH}$ Regulated Dimorphism of Candida albicans," FEMS Microbiology Letters, Vol. 80, No. 2-3, 1991, pp. 333-336. doi:10.1111/j.1574-6968.1991.tb04685.x

[45] M. Casanova, A. M. Cervera, D. Gozalbo and J. P. Martinez, "Hemin Induces Germ Tube Formation in Candida albicans," Infection and Immunology, Vol. 65, No. 10, 1997, pp. 4360-4364.

[46] C. Westwater, E. Balish and D. A. Schofield, "Candida albicans-Conditioned Medium Protects Yeast Cells from Oxidative Stress: A Possible Link between Quorum Sensing and Oxidative Stress Resistance," Eukaryotic Cell, Vol. 4, No. 10, 2005, pp. 1654-1666. doi:10.1128/EC.4.10.1654-1661.2005

[47] E. Mattia and A. Cassone, "Inducibility of Germ-Tube Formation in Candida albicans at Different Phases of Yeast Growth," Microbiology, Vol. 113, No. 2, 1979, pp. 439-442. doi:10.1099/00221287-113-2-439

[48] K. V. Clemons, J. L. Spearow, R. Parmar, M. Espiritu and D. A. Stevens, "Genetic Susceptibility of Mice to Candida albicans Vaginitis Correlates with Host Estrogen Sensitivity," Infection and Immunology, Vol. 72, No. 8, 2004, pp. 4878-4880. doi:10.1128/IAI.72.8.4878-4880.2004

[49] F. Sabie and G. M. Gadd, "Induction of Germ-Tube Formation by Candida albicans in Amino Acid Liquid Synthetic Medium at 25 Degrees C,” Mycopathologia, Vol. 101, No. 2, 1988, pp. 77-83. doi:10.1007/BF00452890

[50] H. Tournu, G. Tripathi, G. Bertram, S. Macaskill, A. Mavor, L. Walker, F. C. Odds, N. A. Gow and A. J. Brown, "Global Role of the Protein Kinase Gcn2 in the Human Pathogen Candida albicans," Eukaryotic Cell, Vol. 4, No. 10, 2005, pp. 1687-1696. doi:10.1128/EC.4.10.1687-1696.2005

[51] D. C. Johnson, K. E. Cano, E. C. Kroger and D. S. McNabb, "Novel Regulatory Function for the CCAATBinding Factor in Candida albicans," Eukaryotic Cell, Vol. 4, No. 10, 2005, pp. 1662-1676. doi:10.1128/EC.4.10.1662-1676.2005

[52] M. Bruatto, M. Gremmi, A. Nardacchione and M. Amerio, "Effect of Glucose Starvation on Germ-Tube Production by Candida albicans,” Mycopathologia, Vol. 123, No. 2, 1993, pp. 105-110. doi:10.1007/BF01365088

[53] H. Lotz, K. Sohn, H. Brunner, F. A. Muhlschlegel and S. Rupp, "RBR1, a Novel pH-Regulated Cell Wall Gene of Candida albicans, Is Repressed by RIM101 and Activated by NRG1,” Eukaryotic Cell, Vol. 3, No. 3, 2004, pp. 776784. doi:10.1128/EC.3.3.776-784.2004 
[54] B. Enjalbert and M. Whiteway, "Release from QuorumSensing Molecules Triggers Hyphal Formation during Candida albicans Resumption of Growth,” Eukaryotic Cell, Vol. 4, No. 7, 2005, pp. 1203-1210. doi:10.1128/EC.4.7.1203-1210.2005

[55] M. Cornet, F. Bidard, P. Schwarz, G. Da Costa, S. Blanchin-Roland, F. Dromer and C. Gaillardin, "Dele- tions of Endocytic Components VPS28 and VPS32 Affect Growth at Alkaline $\mathrm{pH}$ and Virulence through both RIM101-Dependent and RIM101-Independent Pathways in Candida albican," Infection and Immunology, Vol. 73, No. 12, 2005, pp. 7977-7987.

doi:10.1128/IAI.73.12.7977-7987.2005 